\title{
PERAN ORGANISASIONAL TERHADAP PENGEMBANGAN BAHAN AJAR PENGAUDITAN BERBASIS ISA: PERSPEKTIF DOSEN PENGAUDITAN
}

\author{
Eka Noor Asmara' ${ }^{1}$, Supardi ${ }^{2}$, dan Sidiq Ashari ${ }^{3}$ \\ ${ }^{1}$ Akademi Akuntansi YKPN \\ ${ }^{2}$ Akademi Akuntansi YKPN \\ ${ }^{3}$ Akademi Akuntansi YKPN \\ *Email corresponding author:eka.asmara@yahoo.com
}

\begin{abstract}
Abstrak
Pengadopsian International Standards on Auditing (ISA) oleh IAPI sebagai standar audit yang baru di Indonesia merupakan sesuatu yang tidak dapat ditolak. Dengan penerapan standar tersebut, menyebabkan materi atau bahan ajar matakuliah pengauditan harus disesuaikan dengan standar yang digunakan. Akibatnya, pengimplementasian standar ISA pada praktek pengauditan di Indonesia dapat menyebabkan perguruan tinggi harus menyesuaikan bahan ajar yang sesuai dengan standar ISA. Penelitian ini bertujuan untuk menguji hubungan dukungan organisasi dan faktor individu pada penggunaan bahan ajar pengauditan berbasis ISA. Metode pengumpulan data dilakukan secara survey. Variabel yang digunakan adalah dukungan organisasi diwakilkan oleh variabel training, sedangkan variabel individu akan diukur dengan menggunakan variabel self-efficacy. Analisis menggunakan structural equation modeling. Hasil penelitian menunjukkan bahwa seluruh hipotesis yaitu hubungan antara training dan self efficacy dengan cakupan bahan ajar terdukung secara signifikan. Dengan demikian, penelitian ini telah berhasil mengembangkan teori institutional isomorfisme. Temuan dari hasil uji hipotesis mengindikasikan dukungan organisasi dalam bentuk training menjadi sarana yang baik untuk meningkatkan kemampuan dosen agar dapat menjalankan tugasnya semakin baik dan profesional. Profesionalisme sendiri merupakan sumber penting dari lahirnya isomorfisme normatif.
\end{abstract}

Kata kunci: ISA, institutional isomorfisme, isomorfisme mimetic, isomorfisme normatif, training, self-efficacy.

\begin{abstract}
The adoption of International Standards on Auditing (ISA) by IAPI as a new auditing standard in Indonesia is unavoidable choice. As a consequences, alteration of teaching materials on higher education into ISA is considered as a necessary step that has to be taken. If the presumption of institutional isomorfism is taken place by IAPI, the feared of unwellprepared higher education and lectures in the process of adoption and integration new auditing standard has a reasonable reasons. This research is conducted to examine relationship of organization support and individual factor in the process of developing and teaching of audit course material to conform to ISA. Data collection in this research is based on survey that has been used in many similar researches. Training variable represent organization support as well as self-efficacy represent individual variable. Structural equation modeling is applied in this research. Finding of this research demonstrate that hypothesis of relationship between training and self-efficacy and teaching material is significantly supported so that this research elaborate institutional theory of institutional isomorphism. Finding of hypothesis examination indicates that organization support in the form of training could be a proper medium to increase lecturer competency especially in the ISA implementation. Furthermore, professionalism itself could be an important root for the creation of isomorphism norm.
\end{abstract}

Keywords: ISA, institutional isomorphism, isomorphism mimetic, isomorphism norm, training, self-efficacy. 


\section{PENDAHULUAN}

Sejak Securities and Exchange Commission (SEC)mengusulkan roadmap yang mendorongpengadopsian International Financial ReportingStandards (IFRS) yang principle-based secaramandatory bagi perusahaan publik di Amerika dan Parlemen Uni Eropa (UE)meloloskan regulasi yang mensyaratkan semuaperusahaan publik yang terdaftar di Uni Eropa untukmengadopsi IAS/IFRS mulai 1 Januari 2005(Soderstorm and Sun, 2007, dalam Widiastuti, 2011), maka mulai tanggal 1 Januari 2012, Indonesia telah menggunakan standar akuntansi keuangan (SAK) yang merupakan kovergensi dengan International Financial Reporting Stadards (IFRS) dan diwajibkan bagi perusahaan publik. Sedangkan bagi perusahaan non publik menggunakan SAK ETAP (Entitas Tanpa Akuntabilitas Publik). Perkembangan dan perubahan peraturan akuntansi di dunia internasional berpengaruh pula pada praktik akuntansi dan pengauditan di Indonesia. Dengan diberlakukannya standar akuntansi keuangan berbasis IFRS dan sesuai dengan komitmen Institut Akuntan Publik Indonesia (IAPI) sebagai organisasi akuntan publik yang independen, mandiri dan berbadan hukum serta berdasarkan komitmen sebagai anggota International Federation of Accountants (IFAC), IAPI berketetapan untuk mengimplementasikan InternationalStandards on Auditing (ISA) yang diterbitkan oleh International Auditing and Assurance Standards Board (IAASB) sebagai standar audit yang baru, terhitung mulai tanggal 1 Januari 2013 (Jusup, 2014).

Keputusan untuk mengadopsi dan mengimplementasikan standar ISA di Indonesia disebabkan juga karena adanya kekuatan pasar yang dimiliki oleh Kantor Akuntan Publik (KAP) yang beroperasi di Indonesia (Tuanakotta, 2013). Tuanakotta (2013) mengatakan bahwa yang dimaksud dengan kekuatan pasar adalah KAP yang mempunyai jaringan global (Big Four) dan jaringan internasional (second tier firms) melayani klien global dan internasional yang mengadopsi standar-standar IFAC. Bagi KAP yang melayani klien audit semacam itu, ISA bukan lagi pilihan atau lebih tepatnya "pilih ISA atau pilih keluar dari jaringan kerjasama global atau jaringan kerjasama internasional". Berdasarkan ketetapan yang diambil oleh IAPI tentang keharusan untuk mengadopsi dan mengimplementasikan standar ISA, secara teoritis yang dilakukan oleh IAPI merupakan bentuk dariinstitutional isomorfisme atau upaya meniru yang dilakukan suatu lembaga terhadap lembaga yang sama di negara lain yang dinilai lebih maju penyelenggaraan praktik pengauditan.

Menurut DiMaggio dan Powell (1983) yang dimaksud dengan institutional isomorfisme adalah organisasi akan mengidentifikasi tiga mekanisme untuk perubahan atau upaya yang dilakukan organisasi untuk menyesuaikan diri dengan lingkungannya melalui isomorpisme koersif, isomorpisme mimetik, dan isomorpisme normatif. Sehingga dapat dikatakan bahwaimplementasi ISA yang dilakukan oleh IAPI sebagai standar audit baru lebih didominasi oleh desakan dari luar yakni kepatuhan kepada aturan baku formal, tanpa melakukan pengembangan standar baru secara baik.Jika hal ini benar-benar terjadi, maka implementasi standar ISA oleh IAPI dapat menimbulkan isomorpisme koersif. Sehingga paksaan atau tekanan dari suatu peraturan atas suatu pelaksanaan kebijakan, dapat menimbulkan masalah berupa ketaatan semu oleh lembaga atau instansi yang dituntut (Gudono, 2014). Gudono menyatakan bahwa sikap meniru dan 
Peran organisasional terhadap pengembangan bahan ajar...

desakan dari luar untuk patuh kepada aturan baku formal merupakan akibat dari institutional isomorfisme terutama mimetic isomorphism dan coercive isomorphism.

Desakan pengadopsian standar ISA dalam praktek pengauditan di Indonesia mengakibatkan perguruan tinggi harus merespon dengan cepat perubahan bahan ajar matakuliah pengauditan. Dosen dan mahasiswa sangat membutuhkan pengetahuan yang komprehensif mengenai gagasan-gagasan dasar dan proses audit berbasis ISA.Sehingga, diharapkandosen dan mahasiswa dapat menjawab apa, mengapa dan bagaimana standar serta aturan ISA berlaku (Tuanakotta, 2013). Berdasarkan hal tersebut, perguruan tinggi sebagai institusi yang terikat dengan peraturan dan ketentuan yang sama akan cenderung untuk menyesuaikan dengan lingkungannya (isomorpisme koersif), meniru hal-hal yang telah dilakukan perguruan tinggi lainnya (isomorpisme mimetik) dan melakukan kegiatan yang sama untuk menjadikan individunya lebih profesional (isomorpisme normatif). Sehingga isomorphism sebagai "constraining process" yang memaksa satu unit di dalam populasi untuk memiliki wujud atau sifat yang sama dengan unit yang lain dalam menghadapi kondisi lingkungan yang sama (Gudono, 2014).

Pengadopsian standar ISA pada praktek pengauditan di Indonesia akan memunculkan pertanyaanpertanyaan terutama mengenai kesiapan dosen dan perguruan tinggi, seperti bagaimana kesiapan pendidikan akuntansi dalam mengimplementasikan standar ISA sebagai kurikulum pendidikan dan seberapa jauh kesiapan dosen dalam menguasai dan mengintegrasi standar ISA menjadi materi dalam matakuliah pengauditan. Untuk menjawab pertanyaan-pertanyaan tersebut, dibutuhkan penelitian yang menguji dan mendapatkan bukti empiris. Sepanjang pengetahuan peneliti, masih jarangpenelitian di Indonesia yang mencoba menguji kesiapan dosen akuntansi terutama yang mengampu matakuliah pengauditan dalam pengadopsian standar ISA sebagai bahan ajar. Sehingga faktor-faktor yang dapat mempengaruhi kesiapan dosen pengauditan dalam memberikan materi kuliah masih belum diteliti secara mendetail.

Penelitian ini merupakan pengembangan dari hasil penelitian Korzaan dan Boswell (2008); Widiastuti (2011); dan Sofyani dan Akbar (2013), akan tetapi yang membedakan penelitian ini terutama dengan penelitian Sofyani dan Akbar (2013)adalah penelitian ini menggunakan obyek penelitian di perguruan tinggi dan yang menjadi sampel penelitian adalah dosen pengampu matakuliah pengauditan. Alasan penelitian ini dilaksanakan dengan obyek perguruan tinggi adalah perguruan tinggi merupakan lembaga nirlaba yang dalam menjalankan aktivitas pendidikan tidak mencari keuntungan sebesar-besarnya dan setiap kegiatan yang dilakukan harus mengacu kepada peraturan yang berlaku. Sedangkan pemilihan dosen akuntansi yang mengajar matakuliah pengauditan sebagai sampel penelitian disebabkan karena dosen merupakan pihak yang bertanggung jawab terhadap kemampuan mahasiswa dalam memahami materi kuliah yang diajarkan dan dosen merupakan bagian dari institusi perguruan tinggi dan sangat memberikan pengaruh terhadap kinerja perguruan tinggi. Selain ini, penelitian ini merupakan penelitian awal mengenai factor-faktor yang mempengaruhi perilaku individu dalam mengadopsi standar ISA sebagai bahan ajar matakuliah pengauditan. 
Variabel yang digunakan dalam penelitian ini merupakan variabel penelitian yang digunakan dalam model penelitian Cavalluzzo dan Ittner (2004); Korzaan dan Boswell (2008); Widiastuti (2011); dan Sofyani dan Akbar (2013). Faktor organisasional yang digunakan dalam penelitian ini adalah variabel pelatihan (training) yang dilakukan oleh organisasi untuk meningkatkan kemampuan individu dan digunakan dalam penelitian Cavalluzzo dan Ittner (2004) dan Sofyani dan Akbar (2013). Nurkhamid (2008) menyampaikan bahwa pelatihan dapat menjadi sarana bagi para pegawai untuk memahami, menerima, dan merasakan secara nyaman inovasi yang hadir, serta mengurangi tekanan atau kebingungan para pegawai atas tuntutan proses implementasi suatu inovasi yang hadir. Sedangkan faktor individual yang digunakan dalam penelitian ini adalah self efficacy yang tinggi(McClelland 1973; McRae dan Costa 1986; Lee dan Bobko 1994; Robbins 1998; McElroy et al. 2007; Korzaan dan Boswell, 2008; Sofyani dan Akbar, 2013). Lee dan Bobko (1994) mengemukakan bahwa individu yang memiliki self efficacy yang tinggi akan mencurahkan fokusnya untuk mencapai tujuan atau kinerja yang ditetapkan. Hal ini mengindikasikan bahwa self efficacy mempunyai pengaruh terhadap hubungan antara penetapan tujuan dan kinerja individu (Robbins 1998).

Berdasarkan penjelasan tersebut, maka pertanyaan penelitian yang diajukan adalah "Apakah faktor-faktor individual (self efficacy)dan organisasional (training) dapat menjelaskan fenomena-fenomena isomorfisme dalam rangka pengadopsian International Standards on Auditing pada cakupan bahan ajar di matakuliah Pengauditan? Untuk menjawab pertanyaan yang diajukan dalam penelitian ini dan sesuai dengan penjelasan dalam latar belakang masalah, maka penelitian ini bertujuan untuk menganalisis dan memberikan bukti secara empiris apakah faktor individual (self efficacy) dan faktor organisasional (training) dapat memprediksi dan menjelaskan adanya gejala isomorphism dalam pengadopsian dan pengimplementasian standar ISA terhadap cakupan bahan ajar di matakuliah pengauditan. Selain itu, penelitian ini diharapkan akan memberikan kontribusi dalam pengembangan teori Isomorpisme Institusional, khususnya terkait aspekaspek yang penting diperhatikan agar tujuan diadakannya penerapan standar audit berbasis ISA sebagai materi pengajaran matakuliah pengauditan benar-benar dapat tercapai secara substansial dan normatif.

\section{TINJAUAN PUSTAKA DAN PENGEMBANGAN HIPOTESIS}

\section{Teori Institusional}

Teori institusional adalah konsep yang luas dan terus mengalami perkembangan serta memiliki sejarah yang panjang (Gudono, 2012). Menurut Dacin dkk., (2002, dalam Sofyani dan Akbar, 2013), teori institusional merupakan penjelasan populer dan kuat untuk tindakan individu dan organisasi. Teori institusional memaknai keberadaan organisasi dipengaruhi oleh tekanan normatif yang kadang-kadang timbul dari sumber eksternal seperti lingkungan, namun bisa juga timbul dari dalam (internal) organisasi itu sendiri.Menurut Lewis dkk., (2003) secara konseptual teori institusional dapat menjelaskan bagaimana dan mengapa tindakan yang dilakukan oleh individual dalam organisasi secara signifikan dipengaruhi oleh norma-norma, nilai-nilai, budaya dan sejarah organisasi. SedangkanSelznick (1957, dalam DiMaggio 
Peran organisasional terhadap pengembangan bahan ajar...

\& Powell, 1983) mengatakan bahwaorganisasi sebagai sistem rasional berperan melalui pimpinan dan anggotanya untuk mencapai tujuan dalam cara yang efisien.

Pondasi awal instutisionalisme dan penerapannya pada organisasi diikhtisarkan oleh Selznick (dalam DiMaggio \& Powell, 1983) yang dikenal dengan old institusionalism. Pendekatan ini mengatakan bahwa organisasi sebagai sistem rasional berperan melalui pimpinan dan anggotanya untuk mencapai tujuan dalam cara yang efisien. Perkembangan teori institusional dilanjutkan oleh DiMaggio \& Powell (1983) dengan konsep new institusionalismyaitu memberikan penekanan pada operasi organisasi dalam sebuah simbol matrik dari praktik dengan tujuan untuk menyatakan legitimasi.Organisasi yang memiliki legitimasi akan mempunyai isomorfisme yang sama dan dapat menyesuaikan diri terhadap organisasinya (DiMaggio dan Powell, 1983).Organisasi yang beroperasi dalam lingkungan yang sama bereaksi serupa dan seiringnya membangun respon serupa atau mengadopsi praktik serupa ketika diperhadapkan pada situasi tertentu. Organisasi menjadi serupa (homogeny) dengan lainnya pada lingkungan yang sama sebagai hasil dari kekuatan isomorfis. Oleh karena itu, isomorfisme didefinisi sebagai suatu proses mengekang yang memaksa satu unit dalam sebuah populasi untuk menyerupai unit lain yang menghadapi set kondisi lingkungan yang sama (DiMaggio and Powell, 1983).

Menurut DiMaggio dan Powell (1983) ada dua tipe isomorfisme yaitu isomorfisme kompetitif dan isomorfisme institusionalyang digunakan untuk menjelaskan proses homogenisasi. Menurut Meyer (1979) dan Fennell (1980, dalam Sofyani dan Akbar, 2013), isomorpisme kompetitif (competitive isomorphism) adalahasumsi rasionalitas sistem yang menekankan persaingan pasar, perubahan yang bagus, dan pengukuran kesesuaian. Sedangkan isomorbisme institusional (institutional isomorphism) merupakanorganisasi bersaing tidak hanya unt 11 nber daya dan pelanggan, tetapi untuk kekuasaan legitimasi politik dan institusional, serta untuk kesesuaian sosial dan ekonomi. Tekanan yang muncul dalam institutional, menimbulkan tiga mekanisma perubahan dalam institutional isomorfisme, yaitu:(1) Isomorfisme koersif, DiMaggio dan Powell (1983) menjelaskan bahwa isomorfisme koersif muncul karena adanya tekanan internal dan eksternal yang berasal dari organisasi lain yang di dalamnya saling bergantung satu sama lain dan terdapat fungsi organisasi, misalnya aturan yang telah ditetapkan oleh pemerintah.Tekanan dari luar berupa pengaruh politik menjadi hal yang paling berdampak terhadap perubahan organisasi publik (Ashworth dkk., 2009, dalam Binawati, 2015). Dengan adanya tekanan yang diterima oleh organisasi dapat menimbulkan kepatuhan pegawai dalam organisasi; (2) Isomorfisme mimetic,DiMaggio dan Powell (1983) menjelaskan bahwa isomorfisme mimetic merupakan tindakan yang dilakukan oleh suatu organisasi dengan meniru standar praktik dan kebijakan yang digunakan oleh organisasi publik yang lain. Isomorpisme mimetik atau meniru-niru, terjadi ketika teknologi organisasi kurang dipahami (March dan Olsen,1976, dalam Sofyani dan Akbar, 2013), ketika tujuan yang ambigu, atau ketika terdapat ketidakpastian lingkungan yang simbolik (Wijaya dan Akbar 2013), maka organisasi akan cenderung menjadikan diri mereka sebagai model yang sama seperti organisasi lain dan mendorong 
organisasi untuk melakukan imitasi.Isomorpisme yang sifatnya mimetik atau imitasi dapat memicu masalah, yakni kecenderungan untuk terjebak pada pelaksanaan suatu mekanisme kerja yang sifatnya sebatas seremonial formal, bukan berorientasi pada substansi (Gudono, 2012); (3) Isomorfisme normatif, DiMaggio dan Powell (1983) menjelaskan bahwa isomorfisme normatif merupakan bentuk keprofesionalan kerja dalam suatu komunitas organisasi yang didasarkan atas tujuan dan legitimasi, misalnya adalah adanya training dan sertifikasi untuk para kelompok profesi yang merupakan bentuk dari sebuah paksaan organisasi.Bentuk isomorfisme normatif lebih sulit diidentifikasi dibandingkan dua bentuk isomorfisme lainnya. Pengaruh normatif merujuk pada shared norms anggota organisasi (Ryan \&Purcel, 2004, dalam Manafe, 2013). Konsep ini terjadi apabila norma terinternalisasi dalam organisasi sejalan dengan tekanan sosial koersif eksternal. Elemen normatif lingkungan institusi menyebabkan keserupaan kognitif melalui pelatihan, jalur karier, dan konsepsi profesi (Ryan \& Purcell, 2004, dalam Manafe, 2013).

\section{Self Efficacy}

Self efficacy mempunyai akar teori di social cognitive theory oleh Bandura (1977, dalam Hartono, 2008). Menurut Bandura (dalam Hartono, 2008), social cognitive theory merupakan teori yang berbasis pada premis bahwa pengaruh-pengaruh lingkungan semacam tekanan-tekanan sosial atau karakteristikkarakteristik situasional unik, kognitif dan faktor-faktor personal lainnya termasuk personaliti dan juga karakteristik-karakteristik demografik, dan perilaku saling mempengaruhi satu dengan yang lainnya. Sebagai salah satu faktor individu yang dihasilkan pada social cognitive theory,self efficacy dinyatakan sebagai pertimbangan-pertimbangan tentang seberapa baik seseorang dapat melakukan tindakantindakan yang dibutuhkan untuk menghadapi situasi-situasi prospektif (Bandura dkk., 1977). Selanjutnya bandura (1982) seperti dikutip oleh Harrison dan Rainer (1992, dalam Hartono, 2008) mendefinisikan self efficacy sebagai suatu estimasi dari kemampuan seorang untuk melakukan perilaku sasaran dengan berhasil. Sedangkan menurut Hartono (2008), self efficacy adalah kepercayaan-kepercayaan tentang kemampuan seseorang untuk melakukan suatu perilaku tertentu. Self efficacy mempengaruhi pilihanpilihan tentang melakukan perilaku, usaha dan persistensi untuk menghadapi halangan-halangan mencapai kinerja dari perilaku.

Hartono (2008) menyatakan bahwa dalam mendefinisikan self efficacy, sangat penting untuk meninjau dimensi dari self efficacy yang relevan yaitu besaran (magnitude), kekuatan (strength) dan generalisabilitas (generalizability). Besaran dari self efficacy berhubungan dengan tingkat kesulitan tugas yang dipercaya individu dapat melakukannya. Seseorang dengan besaran yang tinggi akan melihat dirinya sendiri mampu untuk menyelesaikan tugas-tugas yang rumit. Sedangkan yang memiliki besaran rendah, akan melihat dirinya sendiri hanya mampu melakukan tugas-tugas yang sederhana dari perilaku. Kekuatan dari self efficacy berhubungan dengan tingkat keyakinan seseorang tentang pertimbangan yang akan dilakukan. Individual dengan kekuatan lemah dari self efficacy akan lebih mudah frustasi karena 
Peran organisasional terhadap pengembangan bahan ajar...

adanya halangan yang menghambat kinerja mereka. Kebalikannya, individual dengan kekuatan yang kuat dari self efficacy tidak akan gentardengan permasalahan sulit. Generalisabilitas dari self efficacy menunjukkan seberapa jauh persepsi dari self efficacy terbatas pada situasi-situasi tertentu. Masingmasing individu akan merasa memiliki kemampuan yang berbeda-beda dalam melakukan perilaku pada kondisi yang berbeda.

Beberapa penelitian telah membuktikan pengaruh self efficacy terhadap keputusan-keputusan tentang perilaku yang akan dilakukan (Bandura dkk., 1977; Betz dan Hackett, 1981; dalam Hartono, 2008), respon-respon emosional (termasuk stress dan kecemasan) dari individual yang melakukan perilakuperilaku (Bandura dkk., 1977; Stumpf dkk., 1987; dalam Hartono 2008), dan pencapaian kinerja sebenarnya dari individual yang berhubungan dengan perilaku (Wood dan Bandura, 1989, dalam Hartono, 2008). Selain itu, dalam konteks manajemen dan organisasi telah ditemukan hubungan antara self efficacy dengan kehadiran, pilihan dan pengembangan karir, produktivitas penelitian dan kinerja penjualan (Hartono, 2008).

\section{Pengembangan Hipotesis}

\section{Hubungan Dukungan Organisasi dan Cakupan Materi Berbasis ISA}

Peran faktor institusional dalam mempengaruhi perilaku individual telah menjadi subyek yang menarik dalam penelitian (Lewis dkk., 2003). Scott (1995, dalam Lewis dkk., 2003) mengidentifikasi tiga cara bagaimana faktor-faktor institusional mempengaruhi kognisi dan perilaku individual melalui tiga pengaruh, yaitu signifikasi (signification) yang berarti individual-individual menggunakan informasi dari institusi untuk memahami bagaimana mereka seharusnya membentuk kepercayaan-kepercayaan tentang hal-hal baru yang dikenalkan di dalam organisasi. Legitimasi (legitimation) berupa berita-berita yang berasal dari manajemen puncak yang digunakan sebagai bentuk-bentuk normatif untuk meyakinkan seseorang tentang legitimasi organisasional tentang kepercayaan-kepercayaan dan tindakan-tindakan. Dan yang terakhir adalah dominasi (domination) menunjukkan situasi yang mana organisasi meregulasi kepercayaan-kepercayaan individual. Pengaruh yang diberikan organisasi terhadap individu melalui signifikasi, legitimasi dan dominasi jika dilihat dari segi teoritis adalah bentuk isomorpisme agar organisasi dapat memperoleh legitimasi dari lingkungannya. Dalam beberapa kondisi, tekanan-tekanan (coercion) yang ada mengarahkan organisasi pada unsur yang dilegitimasi, seperti prosedur standar operasi untuk mencapai profesionalisme, serta memiliki pengaruh untuk mengarahkan perhatian pada kinerja organisasi (Zucker, 1987 dalam Sofyani dan Akbar, 2013).

Cavalluzzo dan Ittner (2004) mengemukakan faktor-faktor organisasional dapat mempengaruhi keberhasilan penerapan peraturan baru dalam konteks penelitian pada pemerintah daerah adalah komitmen manajemen, otoritas pembuatan keputusan, dan pelatihan. Sejalan dengan Cavalluzzo dan Ittner (2004), Widiastuti (2011) mengatakan bahwa faktor organisasional merupakan hal penting yang 
dapat mempengaruhi perilaku individu dalam konteks penelitian pengadopsian standar dalam matakuliah akuntansi. Widiastuti (2011), menyatakan bahwa dukungan institusi atau organisasional merepresentasi kepeduliandan kontrol terhadap apa yang ingin dicapai oleh organisasi terhadap kemajuan individu dan organisasi itu sendiri.Dukungan institusiterhadap perkembanganindividu dalam rangka meningkatkan kemampuan dapat dilakukan dalam bentuk kerja samadengan institusi lain yang lebih baik, menyelenggarakan pelatihan, forumdiskusi baik internal maupun terbuka untukumum, dan mengirimkan individu keberbagai pelatihan yang diselenggarakan institusilain (Widiastuti, 2011). Nurkhamid (2008, dalam Sofyani dan Akbar, 2013) menyampaikan bahwa dukungan institusi dalam bentuk pelatihan dapat menjadi sarana bagi para pegawai untuk memahami, menerima, dan merasakan secara nyaman inovasi yang hadir, serta mengurangi tekanan atau kebingungan para pegawai atas tuntutan proses implementasi suatu inovasi yang hadir.

DiMaggio dan Powell (1983) serta Gudono (2014) menyatakan bahwa pelatihan-pelatihan yang dilakukan organisasi terutama yang bersifat formal dapat meningkatkan kemampuan individu, akan tetapi jika dilihat dari kacamata teori isomorpisme institusional dapat menjadi faktor pendorong lahirnya isomorpisme normatif di suatu lembaga. Walaupun pelatihan tersebut dapat memunculkan terjadinya isomorpisme, menurut kacamata peneliti, dosen yang ditugaskan dan dikirim oleh perguruan tinggi untuk mengikuti pelatihan dapat memberikan pemahaman yang luas terhadap cakupan materi dan dapat meningkatkan kemampuan dosen dalam memahami standar ISA. Sehingga kemampuan dosen akan meningkat dan berakibat pada dosen cenderung lebih menguasai materi dan mampu membahas materi tersebut dalam perkuliahan. Berdasarkan uraian tersebut, maka hipotesis yang dirumuskan adalah sebagai berikut:

H1: Pelatihan yang diberikan organisasi berhubungan positif terhadap cakupan materi pengajaran pengauditan berbasis ISA yang diajarkan kepada mahasiswa.

\section{Hubungan Self Efficacy dan Cakupan Materi Berbasis ISA}

Social cognitive theory merupakan model yang mulai banyak diterima dan secara empiris sudah banyak divalidasi untuk penelitian mengenai perilaku individu. Sebagai teori yang sering digunakan dalam penelitian mengenai perilaku individual, social cognitive theory (Bandura, 1986) menyatakan bahwa hubungan antara kognitif dengan perilaku merupakan refleksi dari hubungan antara pikiran atau ide, perasaan dan tindakan. Selain itu, ekspektasi, kepercayaan-kepercayaan, persepsi-sendiri, tujuan atau cita-cita dan keinginan atau niat memberikan bentuk dan petunjuk untuk berperilaku. Penelitian sebelumnya telah menggunakan social cognitive theory sebagai dasar teori, seperti penelitian yang dilakukan oleh Compeau dan Higgins (1995) dalam konteks pemanfaatan teknologi informasi. Compeau dan Higgins (1995) berdasarkan hubungan timbal-balik segitiga yang dijelaskan dalam social cognitive theory (Bandura, 1986) mengembangkan suatu model yang menunjukkan adanya hubungan saling mempengaruhi antara tiga buah faktor, yaitu faktor kognitif, faktor perilaku dan faktor lingkungan. Hasil 
Peran organisasional terhadap pengembangan bahan ajar...

penelitian tersebut menunjukkan bahwa self-efficacy merupakan karakteristik individual penting yang memoderasi pengaruh organisasi terhadap keputusan individual dalam menggunakan teknologi.

Self efficacy yang berakar pada pada social cognitive theory (Bandura, 1986) adalah persepsi individual mengenai kemampuannya sendiri untuk melakukan suatu perilaku (Lewis, dkk., 2003; Hartono, 2008). Invidu cenderung akan mencurahkan semua perhatiannya untuk mencapai tujuan tertentu dari suatu tugas sepanjang individu tersebut memiliki Self efficacy yang tinggi pada dirinya. Dengan selfefficacy yang tinggi maka dapat menggerakkanmotivasi, kemampuan kognitif, dan tindakan-tindakan yang berkaitan dengan tugasnya (Widiastuti, 2011). Oleh sebab itu, dalam penelitian ini penulis beragumen bahwa self efficacy yang dimiliki oleh dosen terhadap pemahaman materi yang diajarkan akan mempengaruhi cakupan materi kuliah yang digunakan dan diberikan kepada mahasiswa. Dengan demikian, dosen yang memiliki self efficacy tinggi berpotensi menjalankan tugasnya untuk mengajarkan materi kuliah pengauditan yang berbasis ISA sebagai suatu amanat yang harus dilakukan sebaik mungkin dan demi mempertahankan profesionalismenya. Hal ini sejalan dengan pandangan isomorpisme institusional bahwa isomorpisme normatif terkait dengan profesionalisme (Larson 1977; Collins 1979, dalam Sofyani dan Akbar, 2013). Berdasarkan uraian tersebut, maka hipotesis yang dirumuskan adalah sebagai berikut:

H2: Self-efficacy yang dimiliki dosenberhubungan positif terhadap cakupan materi pengajaran pengauditan berbasis ISA yang diajarkan kepada mahasiswa.

\section{METODE PENELITIAN}

\section{Model Penelitian}

Gambar 1 menunjukkan model yang dibangun dalam penelitian ini. Model melibatkan tiga variabel yang berasal dari penelitian-penelitian sebelumnya yaitu, variabel independen yang terdiri dari dukungan organisasi berupa pelatihan dan variabel individu yang diwakilkan oleh self efficacy serta variabel dependen yaitu cakupan bahan ajar berbasis standar ISA untuk mata kuliah pengauditan.

\section{Sampel Penelitian}

Sampel yang digunakan dalam penelitian ini meliputi dosen jurusan akuntansi yang mengajar matakuliah pengauditan pada perguruan tinggi di Yogyakarta. Metode pengambilan sampel yang digunakan dalam penelitianini adalah secara non-probability yaitu purposive sampling. Kriteria yang ditentukan dalam memperoleh sampel penelitian adalah dosen yang masih aktif dan pernah mengajar matakuliah pengauditan. Metoda pengumpulan data dilakukan dengan mengirimkan kuesioner (survey) kepada dosen yang termasuk ke dalam sampel tersebut. Tanggapan dosen yang diperoleh melalui pengisian kuesioner menggunakan skala Likertsesuai dengan pertanyaan masing-masing bagian. 


\section{Alat Analisis}

Penelitian ini menggunakan alat analisis Partial Least Square (PLS) yang digunakan untuk menguji hipotesis yang diajukan. PLS adalah teknik Structural Equation Modeling (SEM) berbasis varian yang secara simultan dapat melakukan pengujian model pengukuran sekaligus pengujian model struktural (Hartono dan Abdillah, 2009). PLS juga bertujuan untuk memprediksi model untuk pengembangan teori. Oleh sebab itu, analisis PLS melibatkan dua tahapan, yaitu menilai model pengukurannya (reliabilitas dan validitas diskriminan dari pengukur-pengukur) dan menilai dari model struktural.

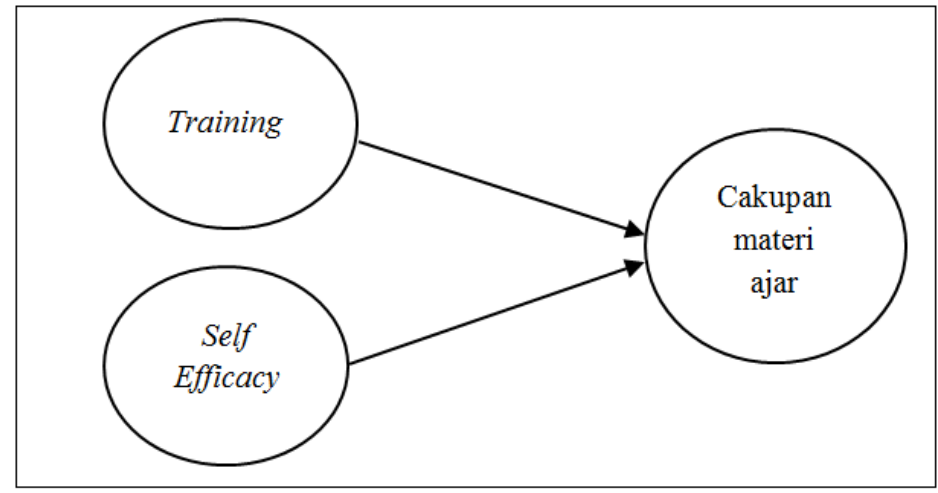

Gambar 1. Model Penelitian

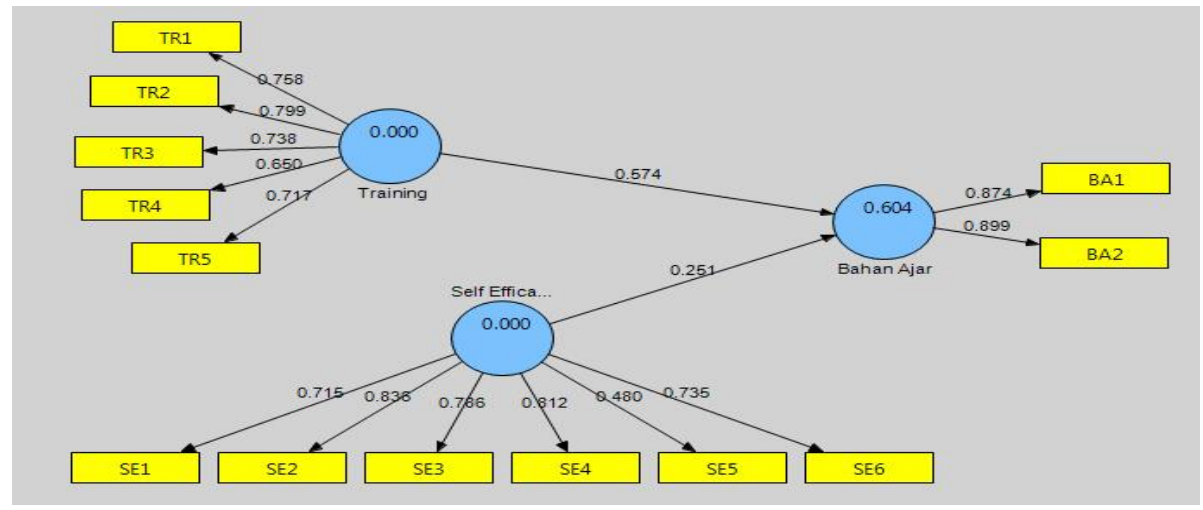

Gambar 2. Tampilan Output Model Pengukuran

Pengujian model pengukuran dilakukan dengan pengujian validitas konstruk dan pengujian reliabilitas. Validitas konstruk terdiri dari validitas konvergen dan validitas diskriminan. Pengujian validitas konvergen dilakukan dengan melihat nilai AVE dan membandingkan antara akar AVE dengan korelasi konstruk variabel laten. Nilai AVE harus > 0,5 sedangkan akar AVE harus lebih tinggi daripada nilai korelasi konstruk lainnya (Hartono dan Abdillah, 2009: 81). Untuk pengujian validitas diskriminan, indikator pada suatu konstruk akan mempunyai nilai loading factor lebih besar pada konstruk yang dibentuknya daripada loading factor pada konstruk lain. Kriterianya loading factor secara praktikal 
Peran organisasional terhadap pengembangan bahan ajar...

memenuhi nilai > 0,50 (Hartono dan Abdillah, 2009: 60). Sedangkan pengujianreliabilitas konstruk dapat diukur menggunakan Cronbach's alpha dan composite reliability.Konstruk dapat dikatakan reliabel jika nilai Cronbach's alpha lebih besar dari 0,60 dan nilai Composite reliability lebih besar dari 0,70(Hartono dan Abdillah, 2009: 81).

Model struktural dalam PLS dievaluasi dengan menggunakan $\mathrm{R}^{2}$ untuk konstruk dependen dan nilai koefisien path atau t-values tiap path untuk uji signifikansi antar konstruk (Hartono dan Abdillah, 2009: 62). Nilai $R^{2}$ digunakan untuk mengukur tingkat variasi perubahan variabel independen terhadap variabel dependen. Tingkat signifikansi pengujian hipotesis ditunjukkan dengan nilai koefiesien path yang ditunjukkan oleh nilai t-statistik. Untuk pengujian hipotesis pada alpha 5\% nilai t-statistik diatas 1,64 untuk hipotesis satu ekor (one-tailed) (Hartono dan Abdillah, 2009: 63).

\section{Definisi Operasional dan Variabel Penelitian}

Dalam penelitian ini, variabel cakupan materi kuliah berbasis standar ISA yang diadopsi dari penelitian yang dilakukan oleh Zhu dkk., (2010) dan Widiastuti (2011). Variabel ini diuji dengan menggunakan pertanyaan yang telah dimodifikasi dan digunakan dalam penelitian Widiastuti (2011). Variabel self efficacydiuji dengan menggunakan pertanyaan pada penelitian Bandura (1986), Compeau dan Higgins (1995); dan Sofyani dan Akbar (2013). Variabel pelatihan diuji dan diukur dengan menggunakan instrumen pertanyaan dari penelitian Cavaluzzo dan Ittner (2004) dan Sofyani dan Akbar (2013). Oleh karena itu, definisi operasional yang digunakan dan instrumen pengukuran variabel dapat dijelaskan sebagai berikut:

\section{Pelatihan(Training)}

Variabel pelatihan merupakan salah satu bentuk dukungan organisasi. Pelatihan yang sudah diberikan oleh organisasi kepada personil organisasi yang terkait dengan peningkatan kinerja terutama mengenai penggunaan standar ISA sebagai bahan ajar matakuliah pengauditan. Variabel ini diukur dengan menggunakan skala 5-item dan masing-masing item menggunakan 5 poin skala Likert.

\section{Self Efficacy}

Keyakinan individu terhadap kemampuannya dalam melaksanakan tugas dan mencapai target kinerja yang telah ditetapkan. Variabel ini diukur dengan menggunakan skala 6-item dan masingmasing item menggunakan 5 poin skala Likert.

\section{Cakupan bahan ajar}

Cakupan bahan ajarmenggambarkan seberapa banyak dosen telahmencakupi atau mengajarkan materi yang sesuai dengan ISA dalam mata kuliah pengauditan. Variabel ini diukur dengan menggunakan skala 2-item dan masing-masing item menggunakan 5 poin skala Likert. 


\section{HASIL DAN PEMBAHASAN}

\section{Gambaran Umum Responden}

Dari 60 kuesioner yang disebarkan ke beberapa perguruan tinggi dan akademi di Yogyakarta,sebanyak 49 kuesioner $(81,67 \%)$ kembali dan dapat diolah karena lengkap serta memenuhi kriteria penyampelan. Dari 49 reponden,29 responden (59,18\%) adalah pria dan sisanya (40,82\%) adalah respondenwanita. Hampir seluruh respondenmemiliki pendidikan terakhir S2 (83,67\%) dan8 responden $(16,33 \%)$ berpendidikan terakhir S3. Dari jumlah responden yang dapat dijadikan sampel penelitian, rata-rata dosen memiliki pengalaman mengajar sekitar 5 sampai 10 tahun.

Data demografi yang dapat diperoleh dari para responden adalah selain bertugas sebagai dosen, beberapa dosen mempunyai pekerjaan sampingan yaitu sebagai konsultan pada suatu perusahaan atau sebagai auditor yang berafiliasi dengan KAP teregistrasi. Hal ini menunjukkan bahwa dosen membutuhkan pengalaman praktek untuk meningkatkan self efficacy dalam rangka mengimplementasikan ke dalam matakuliah akuntansi.

\section{Pengujian Model Pengukuran}

Tabel 1. Tampilan Output Overview Algoritm

\begin{tabular}{ccccccc}
\hline & AVE & $\begin{array}{c}\text { Composite } \\
\text { Reliability }\end{array}$ & $\begin{array}{c}\text { Cronbachs } \\
\text { Alpha }\end{array}$ & $\begin{array}{c}\mathrm{R} \\
\text { Square }\end{array}$ & Communality & Redundancy \\
\hline $\begin{array}{c}\text { Cakupan Bahan } \\
\text { Ajar }\end{array}$ & 0,786603 & 0,880537 & 0,729376 & $\begin{array}{c}0,60440 \\
2\end{array}$ & 0,786603 & 0,215137 \\
\hline Self Efficacy & 0,543178 & 0,874218 & 0,828379 & & 0,543178 & \\
\hline Training & 0,539334 & 0,853534 & 0,786844 & & 0,539334 & \\
\hline \hline
\end{tabular}

\section{Validitas Konvergen}

Validitas konvergen berhubungan dengan prinsip bahwa pengukur-pengukur dari suatu konstruk yang sama seharusnya berkorelasi tinggi. Validitas konvergen dari model pengukuran dinilai berdasarkan loading factor indikator-indikator yang mengukur konstruk tersebut (Hartono dan Abdillah, 2009). Rule of thumb dari nilai loading factor adalah >0,7, akan tetapi menurut Hair dkk. (2010) bahwa untuk nilailoading factor $\geq 0,5$ maka instrumen tersebut telahmemiliki signifikan secara praktikal. Oleh karena itu, penulis memutuskan untuk menggunakan nilai loading factor sebesar >0,5.

Berdasarkan hasil pengujian model pengukuran yang tampak pada Gambar 2 dan ukuran-ukuran yang tampak pada tabel 1 di atas, dapat dijelaskan sebagai berikut.

Variabel cakupan materi atau bahan ajar yang diukur dengan menggunakan indikator BA1 dan BA2, menunjukkan semua indikator memiliki loading factor di atas 0,5 dan memenuhi rule of thumb yang telah 
Peran organisasional terhadap pengembangan bahan ajar...

ditentukan. Selain menggunakan loading factor, pengujian validitas konvergen dapat dilihat dari skor AVE dan Communality yang seluruhnya mendapatkan nilai 0,786603.

Variabel self efficacy yang diukur dengan menggunakan indikator SE1-SE6, diperoleh hasil bahwa indikator SE5 mempunyai nilai loading factor di bawah 0,5 $(0,480)$. Berdasarkan hasil tesebut, peneliti memutuskan untuk tidak mengeluarkan dari pengujian model pengukuran karena pengujian validitas konvergen diperoleh AVE serta Communalitydi atas 0,5 atau lebih tepatnya masing-masing mendapatkan nilai 0,543178 .

Variabel dukungan organisasi yang diwakilkan oleh konstruk pelatihan (training) yang diukur dengan menggunakan indikator TR1-TR5, menunjukkan semua indikator memiliki loading factor di atas 0,5 dan telah memenuhi signifikansi secara praktikal. Selain menggunakan loading factor, pengujian validitas konvergen dapat dilihat dari skor AVE dan Communality yang seluruhnya mendapatkan nilai 0, 539334.Dari hasil penjelasan yang tampak pada Gambar 2 dan Tabel 1 di atas, dapat disimpulkan bahwa semua indikator yang digunakan dalampenelitian inimemiliki nilai loading factordan nilai AVE serta Communalityyang signifikan dan memenuhi rule of thumb validitas konvergen.

\section{Validitas Diskriminan}

Pengukuran validitas diskriminan dari model pengukuran dinilai berdasarkan salah satu dari ukuran cross loading pengukuran atau dengan membandingkan akar average variance extracted(AVE) untuk setiap konstruk dengan korelasi antarakonstruk dengan konstruk lainnya dalam model (Hartono dan

Tabel 2. Average Variance Extracted (AVE) dan Akar AVE

\begin{tabular}{lcc}
\hline \hline & AVE & Akar AVE \\
\hline \hline Cakupan Bahan Ajar & 0,786603 & 0,886906 \\
\hline \hline Self Efficacy & 0,543178 & 0,737006 \\
\hline \hline Training & 0,539334 & 0,734393 \\
\hline \hline
\end{tabular}

Tabel 3. Korelasi Variabel Laten

\begin{tabular}{cccc}
\hline \hline & $\begin{array}{c}\text { Cakupan } \\
\text { Bahan Ajar }\end{array}$ & $\begin{array}{c}\text { Self } \\
\text { Efficacy }\end{array}$ & Training \\
\hline \hline $\begin{array}{c}\text { Cakupan Bahan } \\
\text { Ajar }\end{array}$ & 1,000000 & & \\
\hline \hline Self Efficacy & 0,672700 & 1,000000 & \\
\hline \hline Training & 0,758474 & 0,734152 & 1,000000 \\
\hline \hline
\end{tabular}

Abdillah, 2009). Model mempunyai validitas diskriminan yang cukup jika skor cross loading di atas 0,70 atau akarAVE untuk setiap konstruk lebih besar daripada korelasi antara konstrukdengan konstruk lainnya dalam model.

Dalam penelitian ini, model mempunyai validitas diskriminan yang baik yaitu nilai AVEdan akar AVE untuk setiap variabel atau konstruk mempunyai nilai yang lebih tinggi dibandingkan dengan koefisien korelasi antar tabel pada Tabel 2. Sedangkan koefisien korelasi antar variabel atau konstruk pada Tabel 3, dapat disimpulkan bahwa semua indikator yang digunakan dalam penelitian ini telah memenuhi kriteria validitas diskriminan.

\section{Uji Reliabilitas}

Reliabilitas suatu pengukur menunjukkan stabilitas dan konsistensi dari suatu instrument untuk mengukur suatu konsep atau suatu variabel (Cooper dan Schindler, 2006; Hair dkk., 2010). Pengujian 
reliabilitas dalam PLS dapat diukur dengan melihat nilai Cronbach'salpha dan Composite Reability. Cronbach'salpha mengukur batas bawah nilai suatu konstruk, sedangkan Composite Reabilitymengukur nilai sesungguhnya reliabilitas suatu konstruk (Chin, 1995). Dalam penelitian ini metode uji reliabilitas yang digunakan adalah Composite Reabilitykarenalebih baik dalam mengestimasi konsistensi internal suatu konstruk (Werts dkk., 1974, dalam Hartono dan Abdillah, 2009: 132) Adapun hasil uji reliabilitas konstruk dalam penelitian ini dapat dilihat pada Tabel 4 berikut.

Rule of thumb yang digunakan dalam pengukuran reliabilitas adalah dengan melihat darinilai Cronbach'salpha dan Composite Reability, yaitu harus lebih besar dari 0,7 (Hartono dan Abdillah, 2009: 132). Pada Tabel 4, menunjukkan nilai Cronbach'salpha dan Composite Reabilitydari masing-masing konstruk yang tampak memiliki nilai di atas 0,7 . Sehingga dapat dinyatakan semua pengukur yang dipakai dalam penelitian ini adalah reliable dan masing-masing konstruk yang digunakan dalam penelitian ini memiliki konsistensi dan ketepatan dalam mengukur konsep.

\section{Pengujian Model Struktural}

Hartono dan Abdillah (2009: 133) menyatakan bahwa pengujian structural model dalam PLS dievaluasi dengan menggunakan $\mathrm{R}^{2}$ (R-square) untuk variabel dependen dan nilai koefisien path( $\beta$ )untuk variabel independen yang kemudian dinilai signifikansinya berdasarkan nilai $t$-statistic untuk setiap path atau jalur hubungan antar variabel. Pengujian model struktural dilakukan untuk menilai signifikansi hubunganantara konstruk atau variabel laten dengan konstruk lainnya yang terdapat dalam model penelitian. Hipotesis terdukung jika arah koefisien hasil bootstraping PLS sama dengan arah hipotesis yang dirumuskan (positif) dan memiliki nilai t-statistik lebih besar dari t-tabel (dengan alpha 5\% yaitu 1,64). Tabel 5 menujukkan nilai beta koefisien dan nilai $t$-statistic dari hasil pengujian model struktural.

Tabel 4. Nilai Composite Reliabitity dan Crombach's Alpha

\begin{tabular}{ccc}
\hline & $\begin{array}{c}\text { Composite } \\
\text { Reliability }\end{array}$ & $\begin{array}{c}\text { Cronbacks } \\
\text { Alphar }\end{array}$ \\
\hline Cakupan Bahan Ajar & 0,880537 & 0,729376 \\
\hline Self Efficacy & 0,874218 & 0,828379 \\
\hline Training & 0,853534 & 0,786844 \\
\hline
\end{tabular}


Tabel 5. Koefisien Jalur pada Pengujian Model Struktural

\begin{tabular}{lccccc}
\hline & $\begin{array}{c}\text { Original } \\
\text { Sample } \\
\text { (O) }\end{array}$ & $\begin{array}{c}\text { Sample } \\
\text { Mean } \\
\text { (M) }\end{array}$ & $\begin{array}{c}\text { Standard } \\
\text { Deviation } \\
\text { (STDEV) }\end{array}$ & $\begin{array}{c}\text { Standard } \\
\text { Error } \\
\text { (STERR) }\end{array}$ & $\begin{array}{c}\text { T Statistics } \\
(\text { (SO/STERR|) }\end{array}$ \\
\hline $\begin{array}{l}\text { Training }> \\
\text { Cakupan } \\
\text { Bahan Ajar }\end{array}$ & 0,251323 & $\begin{array}{c}0, \\
256912\end{array}$ & 0,058298 & 0,058298 & 4,311037 \\
\hline \hline $\begin{array}{l}\text { Self Efficacy }> \\
\text { Cakupan } \\
\text { Bahan Ajar }\end{array}$ & 0,573965 & $\begin{array}{c}0, \\
571854\end{array}$ & 0,056252 & 0,056252 & 10,203465 \\
\hline
\end{tabular}

Berdasarkan nilai beta koefisien (original sample) dan t-stastistic yang tampak pada Tabel 5, maka hasil pengujian masing-masing hipotesis dapat dijelaskan. Hipotesis 1 menyatakan bahwa training yang diberikan oleh organisasi kepada dosen dalam rangka peningkatan bahan ajar pengauditan berhubungan positif dengan variabel cakupan bahan ajar. Hasil pengujian koefisien jalur menunjukkan bahwa faktor pelatihan berhubungan secara positif signifikan terhadap cakupan bahan ajar dengan nilai koefisien beta 0,251323 dan $t$-stastistic atau $t$-value sebesar 4,311037. Artinya, hipotesis pertama terdukung dengan tingkat keyakinan $95 \%$ atau $\mathrm{p}<0,05$. Hubungan antara self efficacy dengan variabel cakupan materi atau bahan ajar yang tampak pada hipotesis 2 memiliki hubungan positif signifikan. Hipotesis 2 yang menyatakan hubungan antara self efficacy dengan cakupan materi mendapatkan nilai koefisien beta 0,573965dan t-value sebesar 10,203465. Sehingga, hipotesis 2 tersebut terdukung dengan derajat keyakinan $99,995 \%$ atau $\mathrm{p}<0,005$.

\section{Pembahasan}

Dukungan perguruan tinggi merepresentasi dukungan terhadap perkembangan individu dalam hal ini memfasilitasi individu untuk meningkatkan kemungkinan mengajarkan materi kuliah pengauditan berbasis standar ISA. Menurut Widiastuti (2011), dukungan organisasi bisa diberikan dalam bentuk kerja sama dengan institusi lain yang memiliki pengetahuan yang lebih baik seperti IAI dan Kantor Akuntan Publik (KAP), menyelenggarakan pelatihan, forum diskusi baik internal program studi maupun terbuka untuk umum, dan mengirimkan staf pengajarnya ke berbagai pelatihan yang diselenggarakan institusi lain. Nurkhamid (2008) menyampaikan bahwa pelatihan dapat menjadi sarana bagi para pegawai untuk memahami, menerima, dan merasakan secara nyaman inovasi yang hadir, serta mengurangi tekanan atau kebingungan para pegawai atas tuntutan proses implementasi suatu inovasi yang hadir.

Temuan dari hasil uji hipotesis 1 berbeda dengan hasil yang dicapai oleh Widiastuti (2011) yang menyatakan bahwa dukungan organisasi relatif rendah. Penelitian ini mendapatkan hasil bahwa pelatihan yang diberikan oleh organisasi dapat meningkatkan pemahaman dosen untuk mengajarkan matakuliah pengauditan berbasis standar ISA. Hasil hipotesis 1 inimengindikasikan bahwa dukungan perguruan tinggi berupa mengikutsertakan dosen pada pelatihan untuk memahami standar ISA menjadi sarana yang baik untuk meningkatkan kemampuan dan kapasitas dosen agar dapat menjalankan tugasnya dengan baik 
dan lebih profesional. Walaupun profesionalisme sendiri merupakan sumber penting dari lahirnya isomorpisme normatif (Sofyani dan Akbar, 2013) akan tetapipelatihan dapat menjadi pemicu awal pelaksanaan Standar Audit berbasis ISA agar dapatdilaksanakan dengan sebenar-benar, bukan sebatas pemenuhan kewajiban beban tugas dosen atau hanya sebagai kegiatan meniru perguruan tinggi terhadap kebijakan yang diambil oleh organisasi lainnya. Oleh karenanya, agar implementasi standar audit ISA sebagai bahan ajar kuliah pengauditan, diharapkan setiap perguruan tinggi sebaiknya senantiasa mengupayakan adanya pelatihan yang terstruktur dan berkelanjutan bagi seluruh dosen, guna terus mendorong keberhasilan implementasi bahan ajar pengauditan berbasis ISAhingga menyentuh pada tahap bahan ajar tersebut mudah dipahami oleh mahasiswa serta dapat diterima secara luas baik oleh perguruan tinggi lainnya atau oleh organisasi-organisasi publik lainnya.

Hipotesis 2 yang menyatakan bahwa self efficacy berhubungan secara positif dengan cakupan bahan ajar pengauditan berbasis ISA menunjukkan hasil positif signifikan. Hasil pengujian hipotesis 2 ini mengindikasikan bahwa semakin tinggi self efficacy dosen maka dosen akan semakin sering memberikan materi kuliah pengauditan berbasis ISA. Oleh sebab itu, dosen yang memiliki self efficacy tinggi terhadap kemampuan memahami materi pengauditan berbasis ISA akan lebih memungkinkan untukmengimplementasikanya ke dalam bahan ajar yang diberikan kepada mahasiswa.Sehingga dosen akan melakukan pengajaran dengan sebaik mungkin demi mempertahankan profesionalismenya dan tidak sekedar menggugurkan kewajiban pengajarannya saja.Keberhasilan pelaksanaan implementasi standar audit berbasis ISA pada mata kuliah pengauditan dinilai akan bisa diraiholeh perguruan tinggi khususnya dosen pengampu matakuliah pengauditan jika dosen mempunyai ketekunan, dedikasi, dan kematangan intelektual. Karakter-karakter tersebut berperan penting dalam meningkatkan profesionalitas kerja yang mampu melahirkan isomorfisma normatif (Sofyani dan Akbar, 2013).

Hasil penelitian ini menguatkan pendapat Robbins (2010, dalam Sofyani dan Akbar, 2013) yang mengatakan bahwa organisasi adalah entitas yang ditopang oleh anggota organisasi atau individu yang ada di dalamnya. Argumen tersebut mengisyaratkan bahwa kinerja organisasi yang baik berasal dari pegawai yang memiliki kinerja yang baik pula, dan salah satu pemicupegawai memiliki kinerja yang baik adalah memilikiself efficacy tinggi. Sebagaimana penjelasan Bandura (1986), self efficacy adalah kemampuan individu menilai kapabilitas dirinya dalam mengorganisir dan melaksanakan kegiatankegiatan yang mensyaratkan pencapaian tingkat kinerja tertentu atau menghadapi situasi yang prospektif. Individu yang memiliki self efficacy yang tinggi akan mencurahkan semua perhatiannya untuk mencapai tujuan tertentu dari suatu tugas. Ketika menghadapi hambatan atau kesulitan dalam pencapaian tujuan, individu yang memiliki self efficacy tinggi akan berusaha secara maksimal agar mampu bertahan lebih lama dan berhasil mencapai tujuan atau kinerja yang ditetapkan (Lee dan Bobko,1994). 


\section{KESIMPULAN DAN SARAN KESIMPULAN}

Bandura (1986) menyatakan bahwaself efficacy merupakan kemampuan individu menilai kapabilitas dirinya dalam mengorganisir dan melaksanakan kegiatan-kegiatan yang mensyaratkan pencapaian tingkat kinerja tertentu atau menghadapi situasi yang prospektif. Hal ini mengindikasikan bahwa self efficacy merupakan faktor penting bagi individu untuk mengimplementasikan rencana dan tujuan organisasi. Sebagai pengembangan konsep self efficacy dan teori isomorphism yang diusulkan oleh DiMaggio dan Powell (1983), penelitian ini bertujuan untuk memberikan bukti empiris hubungan faktor dukungan organisasi berupa training danself efficacy dosen dalam mengimplementasikan bahan ajar pengauditan berbasisi ISA.

Hasil penelitian ini memberikan dukungan yang kuat terhadap tujuan tersebut. Hal ini ditunjukkan dengan terdukungnya seluruh hipotesis yang diajukan. Terdukungnya seluruh hipotesis mengindikasikan bahwa dukungan organisasi dengan cara mengirimkan dosen untuk mengikuti pelatihan dapat meningkatkan kemampuan dosen untuk mengimplementasikan ilmu yang diperoleh dalam pelatihan tersebut sebagai materi kuliah. Hasil penelitian ini menunjukkan bahwa responden merasa bahwa perguruan tinggi tempat mereka bekerja, sangat mendukung untuk mengikuti pelatihan-pelatihan guna meningkatkan kompetensi dan profesionalisme mereka. Sehingga para responden merasa yakin untuk melakukan perubahan kurikulum terutama untuk matakuliah pengauditan dari penggunaan standar nonISA ke standar ISA.

\section{KETERBATASAN}

Walaupun hasil penelitian ini menunjukkan keterdukungan terhadap seluruh hipotesisnya, akan tetapi penelitian ini memiliki keterbatasan yang dapat dijadikan sebagai pertimbangan untuk penelitianpenelitian selanjutnya. Pertama, penelitian ini hanya menggunakan responden dengan kemampuan atau keahlian yang spesifik saja yaitu dosen yang mengampu matakuliah pengauditan pada perguruan tinggi di wilayah Yogyakarta. Sehingga kurang mampu menggeneralisasi penggunaan standar-standar yang lainnya secara luas. Kedua, penelitian ini dilakukan dengan pendekatan kuantitatif saja, sehingga memiliki kekurangan dalam menangkap isu fenomena isomorpisme dalam implementasi ISApada matakuliah pengauditan.

Kelemahan ketiga yang ditemukan dalam penelitian ini adalah data penelitian ini merupakan hasil dari persepsi responden berdasarkan instrumen yang diadopsi dari penelitian-penelitian sebelumnya. Menurut Sofyani dan Akbar (2013), penggunaan instrumen dalam penelitian berdasarkan persepsi responden dapat menimbulkan masalah jika persepsi responden berbeda dengan keadaan sesungguhnya. Kelemahan terakhir, indikator-indikator yang digunakan terutama variabel cakupan materi atau bahan ajar merupakan adopsi dari penelitian-penelitian sebelumnya dan dikembangkan sendiri oleh peneliti 
berdasarkan common sense peneliti. Sehingga memungkinkan terjadi perbedaan persepsi dengan responden penelitian.

\section{SARAN}

Terkait dengan keterbatasan yang dijelaskan sebelumnya, beberapa masukan dan saran yang direkomendasikan untuk pengembangan penelitian-penelitian selanjutnya yaitu: pertama, penelitian berikutnya sebaiknya memperluas sampel penelitian, tidak hanyapada sampel yang berasal dari perguruan tinggi yang ada di Yogyakarta tetapi diperluas dengan melibatkan perguruan tinggi dari kotakota lainnya. Sehingga diharapkan dapat memberikan hasil yang lebih bervariasi terhadap pengaruh masing-masing variabel.

Kedua, untuk memperoleh hasil yang lebih baik mengenai fenomena isomorphism, penelitian selanjutnya perlu melakukan model penelitian campuran yaitu penelitian yang dilakukan dengan menggabungkan antara kualitatif dan kuantitatif. Sehingga fenomena isomorphism dapat digali secara mendalam dengan bertanya secara langsung kepada sumbernya. Untuk penelitian selanjutnya, sebaiknya peneliti menambahkan konstruk atau variabel-variabel lainnya yang berhubungan dengan implementasi ISA terhadap bahan ajar pengauditan. Selain itu, penelitian selanjutnya sebaiknya memperbaiki indikator yang digunakan untuk mengukur konstruk cakupan materi atau bahan ajar.

\section{DAFTAR PUSTAKA}

Bandura, A. 1977. Self-Efficacy: Toward a Unifying Theory of Behavioral Change. Psychological Review, Vol. 84, No. 2, hal. 191-215.

Bandura, A. 1986. Social Foundations of Thought and Action: A Social Cognitive Theory. Prentice Hall, Englewood Cliffs, NJ.

Binawati, Enita. 2015. Implementasi Anggaran Berbasis Kinerja dan Akuntabilitas Sektor Publik: Studi Pada Pemerintah DIY. Jurnal Wahana: Jurnal Manajemen, Ekonomi dan Akuntansi, Vol. 18, No. 1, Februari 2015.

Cavalluzzo, K. S. and C. D. Ittner. 2004. Implementing Performance Measurement Innovations: Evidence From Government. Accounting, Organizations and Society, 29, 243-267.

Chin, W. W., 1995. Partial LeastSquares is to LISREL as Principal Components Analysis is to Common Factor Analysis. TechnologyStudies, 2, Hal. 315-319.

Compeau, D., dan Higgins, Christopher A. 1995. Computer Self-Efficacy: Development of a Measure and Initial Test.. MIS Quarterly, Vol. 19, No. 2, Hal. 189-211.

Compeau, D., Higgins, Christopher A., dan Huff, S. 1999. Social Cognitive Theory and Individual Reactions to Computing Technology: A Longitudinal Study. MIS Quarterly, Vol. 23, No. 2, Hal. 145-158.

DiMaggio, P. J., and W. W. Powell. 1983. The Iron Cage Revisited: Institutional Isomorphism and Collective Rationality in Organizational Fields. Dalam W. W. Powell and P. J. DiMaggio (editor). The New Institutionalism in Organizational Analysis. Chicago: The University of Chicago Press.

Fennell, M. L. 1980. The Effects of Environ-mental Characteristics on the Structure of Hospital Clusters. Administrative Science Quarterly, 25, 484-510. 
Peran organisasional terhadap pengembangan bahan ajar...

Gudono. 2012. Teori Organisasi. BP Fakultas Ekonomika dan Bisnis UGM-Yogyakarta, Edisi 2. .2014. Teori Organisasi.BP Fakultas Ekonomika dan Bisnis UGM-Yogyakarta, Edisi 3.

Hair Jr., J.E., Anderson, R.E., Tatham R.L. \& Back, W.C. (2010), Multivariate dataAnalysis, $7^{\text {th }}$ Ed., New Jersey: Prentice-Hall International, Inc.

Hartono, Jogiyanto M 2008. Sistem Informasi Keperilakuan. Edisi Revisi, Andi, Yogyakarta.

Hartono, Jogiyanto M. dan Abdillah, Willy. 2009. Konsep Aplikasi PLS Untuk Penelitian Empiris. BP Fakultas Ekonomika dan Bisnis UGM-Yogyakarta.

Jusup, Al Haryono. 2014. Auditing (Pengauditan Berbasis ISA). Edisi II. Bagian Penerbitan STIE YKPN Yogyakarta.

Korzaan, M. L. and K. T. Boswell. 2008. The Influence of Personality Traits and Information Privacy Concerns on Behavioral Intentions. Journal of Computer Information System, 16-24.

Lee, C., and P. Bobko. 1994. Self Efficacy Belief: Comparation of Measures. Journal of Applied Psychology, $60,187-191$.

Lewis, W., Agarwal, R., Sambamurthy, V. (2003). Sources of Influence on Beliefs about Information Technology Use: An Empirical Study of Knowledge Workers. MIS Quarterly, Vol. 27, No. 4, hal. 657-678.

Manafe, Mesri Welhelmina Nisriani. 2013. Pengaruh Konflik Keharusan Akuntanbilitas Terhadap Kinerja Pemerintah Daerah. Jurnal Wahana: Jurnal Manajemen, Ekonomi dan Akuntansi, Vol. 16, No. 2, Agustus 2013.

McClelland, D. C. 1973. Testing for Competence raher than Intellegence. American Psychologist, 28 (1), 1-14.

McCrae dan Costa. 1986. Clinical Assessment Can Benefit from Recent Advances in Personality Psychology. American Psychologist, 41, 1001-1003.

Nurkhamid, M. 2008. Implementasi Inovasi Sistem Pengukuran Kinerja Instansi Pemerintah. Jurnal Akuntansi Pemerintah, 3 (1), 45-76.

Robbins, S. P. 1998. Organizational Behavior: Foundation, Realities, dan Challenges 2nd Edition. New York: McGraw Hill.

Sofyani, Hafiez dan Akbar, Rusdi. 2013. Hubungan Faktor Internal Institusi dan Implementasi Sistem Akuntabilitas Kinerja Instansi Pemerintah (SAKIP) di Pemerintah Daerah.Jurnal Akuntansi dan Keuangan Indonesia, Volume 10 Nomor 2, Desember 2013.

Tuanakotta, Theodorus M. 2013. Audit Berbasis ISA (International Standards on Auditing). Salemba Empat.

Widiastuti (2011). Kesiapan Dosen Akuntansi dalam Mengintegrasikan Materi IFRS Dalam Mata Kuliah. Fokus Ekonomi (FE), Vol. 10, No. 3, Desember 2011, Hal. 204 - 216.

Wijaya, A. H. C. and R. Akbar. 2013. The Influence of Information, Organizational Objective and Targets, and External Pressure toward The Adoption of Performance Measurement System in Public Sector. Journal of Indonesian Economy and Business, 28, 62-83.

Zhu, H., K. Rich, A. Michenzi., J. Cherubini,(2010), User Educations of IFRS at U.S.Institutions: current status and influencingfactors. 